\title{
Radiation Exposure from Fluoroscopy during Hip Arthroscopy
}

\author{
Roberto Seijas, MD, PhD ${ }^{1,2,3}$ Jordi Català, MD ${ }^{4}$ Miguel Ángel Cepas ${ }^{5}$ Andrea Sallent, MD ${ }^{6(0)}$ \\ Oscar Ares, MD, $\mathrm{PhD}^{70}$ David Barastegui, MD, $\mathrm{PhD}^{1,2,8}$
}

${ }^{1}$ Department of Orthopedic Surgery, Instituto Cugat, Hospital Quirón, Barcelona, Spain

${ }^{2}$ Garcia-Cugat Foundation, Barcelona, Spain

${ }^{3}$ Department of Anatomy, Universidad Internacional de Catalunya, Barcelona, Spain

${ }^{4}$ Department of Radiology, Instituts Guirado, Barcelona, Spain

${ }^{5}$ Hospital Quirón, Barcelona, Spain

${ }^{6}$ Department of Orthopedic, Hospital Vall d'Hebron, Barcelona, Spain

${ }^{7}$ Department of Orthopedic and Trauma, Hospital Clínic Barcelona, Spain

8 Mutualitat Catalana de Futbolistes, Barcelona, Spain
Address for correspondence Roberto Seijas Vázquez, MD, PhD, Department of Orthopedic Surgery, Instituto Cugat, Hospital Quirón Barcelona, Pza. Alfonso Comiín 5-7, Planta -1, 08035 Barcelona, Spain (e-mail: roberto6jas@gmail.com).

Surg J 2019;5:e184-e187.

\begin{abstract}
Keywords

- femoroacetabular impingement

- hip arthroscopy

- fluoroscopy

- radiation exposure

Objective Hip arthroscopy for femoroacetabular impingement treatment is a procedure that is not exempted from complications. The most common complications are related to the arthroscopic portals and the traction system. The use of fluoroscopy helps in hip arthroscopy; however, the radiation exposure is a risk that has not yet been studied.

Materials and Methods A retrospective study with 100 arthroscopies was performed. Surgical indication in all cases was femoroacetabular impingement. Surgical times and radiation exposure during the procedure had been recorded and reviewed for the present study.

Results A mean of $138.20 \mathrm{cGy} \mathrm{cm}^{2}$ radiation exposures was observed per patient and procedure for a mean time of radiation exposure of 0.36 minutes. These values are much lower than the values described as being at risk by the nuclear security commissions.

Conclusions Radiation exposure in a hip arthroscopy due to femoroacetabular impingement is in margins well below the limits at risk for the patient.
\end{abstract}

Femoroacetabular impingement (FAI) has sustained a growing increase in its knowledge and thus in the number of surgeries designed to treat it, as well as a technic and scientific development in the past years. ${ }^{1}$

Despite the arthroscopic procedures have progressed to improve the access to the central and peripheral areas of the hip, ${ }^{2}$ there is an existing risk of injuries, especially when the surgical instruments go over the labrum or the femoral head's cartilage. The use of fluoroscopy helps reducing these

received

July 15, 2019 accepted after revision September 27, 2019
DOI https://doi.org/

10.1055/s-0039-3400278. ISSN 2378-5128. risks, however, with radiation exposure for the patient. Moreover, the risk of radiation exposure may be even greater in patients with a more difficult access to the joint. ${ }^{3}$

In our country, the risks of radiation exposure are regulated according to the recommendations by the European Atomic Energy Community (Euratom) according to the regulations by the Nuclear Safety Commission, and proposed by the Spanish Ministries of Economy, Home Affairs, Health and Social Services, Employment and Social Security, and Defense. ${ }^{4-6}$
Copyright $\odot 2019$ by Thieme Medical Publishers, Inc., 333 Seventh Avenue, New York, NY 10001, USA. Tel: +1(212) 584-4662.
License terms

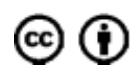


Due to the more complex pathologies that are being treated in hip arthroscopy, ${ }^{1}$ we considered evaluating the radiation exposure that patients receive and know the grade of safety in this field.

Our hypothesis is that radiation received by patients undergoing a hip arthroscopy due to FAI entails a radiation dose within the safety limits established and is therefore reasonable and safe.

\section{Materials and Methods}

A retrospective study with 100 patients was performed, evaluating the radiation exposure of patients undergoing a hip arthroscopy in our center. Inclusion criteria included diagnosis of FAI, age over 18 years old, and no previous pathology of the hip. One single institution surgical and anesthetic team performed all surgeries with the same radiologic technician.

An informed consent was obtained from all participants for the present study.

\section{Surgical Procedure}

The procedures were performed in supine position with intradural anesthesia. Hip arthroscopy was performed in all cases in supine position with a specific hip positioning system (Smith and Nephew, Memphis, TN). The same fluoroscopic C-arm (Philips BV Pulsera, Philips Medical System; Eindhoven, The Netherlands) was used in all surgeries. Longitudinal traction was used in the operative extremity to distract the hip for introduction of the instruments, with foam-padded boots and perineal-padded post to protect skin or nerve injuries due to the traction applied. ${ }^{7}$ The C-arm fluoroscopic arm is brought to the operative field and placed over the operative hip, between the patient's legs, offering an anteroposterior (AP) view of the joint (-Fig. 1). The hip is then gently distracted under fluoroscopic guidance to obtain $\sim 10 \mathrm{~mm}$ distance between the acetabulum and femoral head. A spinal needle is used for the first portal (anterolateral), ${ }^{3}$ and then the guide is removed to pass the Nitinol guidewire (Disposable Hip Pac, Smith \& Nephew, MA), placing an obturator-cannula over. Then, the obturator is removed to introduce the $70^{\circ}$ arthroscope (VideoArthroscope $70^{\circ}$ HD DirectView, Smith \& Nephew, MA). The distal anterior and anterior portals are done under arthroscopic vision to perform the labral suture and treatment of acetab-
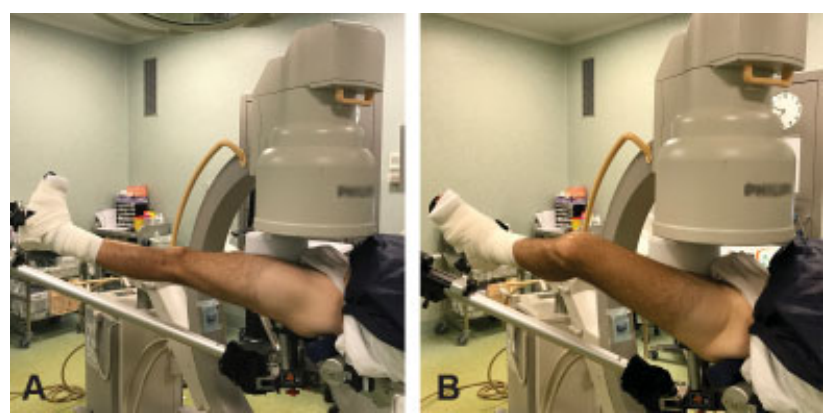

Fig. 1 (A, B) Positioning of the fluoroscopy C-arm in anteroposterior and axial views of the left hip. ular and femoral cartilage lesions. Once the central space has been approached and treated, traction is removed to easily reach the peripheral space of the hip and perform the cervico-cephalic femur osteoplasty under fluoroscopic guidance in AP view and with flexion-rotation of the hip for an axial view (-Fig. 1A and B).

\section{Radiation Exposure}

Evaluation of radiation-absorbed dose by the patient was studied by the dose area product (DAP) $\left(\mathrm{cGy} \mathrm{cm}^{2}\right)$, which is the total radiation energy delivered to the tissues, and the effective dose (E, $\mathrm{mSv}$ ), related directly to radiation-associated risk (stochastic risk). Conversion factor is $0.2 \times \mathrm{DAP}=$ $\mathrm{mSv}$. Twenty millisieverts are equal to $\sim 1,000$ chest $\mathrm{X}$-rays. If 1,000 adult patients are irradiated with $20 \mathrm{mSv}$, it is estimated that at least one of them could die of radio-induced cancer. $^{8,9}$

Accumulative skin dose (Gy) represents the deterministic (direct) effects on the skin. It is defined as the dose that the patient's skin will absorb if the X-ray beam irradiates always the same skin area. Based on DAP it can be approximately worked out. Over 3,000 mGy (3 Gy) should be a dangerous situation that requires a clinical follow-up..$^{8,9}$

High-dose procedure radiation was considered when $5 \%$ of cases exceed DAP of $300 \mathrm{cGy} \mathrm{cm}$. 2,8,9

The skin dose is hard to calculate precisely due to the different variables that are checked out: use of filtrations, different angulations in taking pictures, variability in the field of view's size, etc.; however, skin dose is calculated approximately using the following formula:

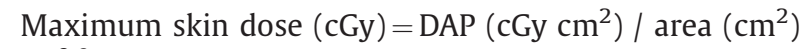
$\times 1.3 .8,9$

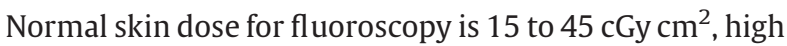

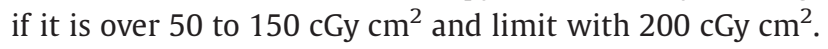

\section{Statistical Analysis}

The descriptive statistical analysis involved the use of tables of absolute frequencies for qualitative variables and measures (mean, median) central tendency and dispersion (standard deviation [SD]) for continuous quantitative variables.

All statistical analysis was performed using SPSS for Mac, version 20 .

\section{Results}

In a retrospective study, 100 consecutive patients with FAI who were undergoing a hip arthroscopy were included. - Table 1 shows epidemiological values of the cases studied.

The type of FAI and the surgical details of labrum management are described in -Table $\mathbf{2}$.

Mean age of patients was 38.5 years old (SD: 14.3), with an average time of fluoroscopy of 0.36 minutes (SD: 0.14 ) (21 seconds). The estimated doses for this population were a DAP of $138.30 \mathrm{cGy} / \mathrm{cm}^{2}$ (SD: 79.39). Therefore, $0.026 \mathrm{mSV}$ of radiation exposure is the equivalent to 1.3 chest $\mathrm{X}$-rays (0.02 mSV). 
Table 1 Epidemiologic data

\begin{tabular}{|l|l|}
\hline & Study group \\
\hline Patient count $(\boldsymbol{n})$ & 100 \\
\hline Age $(\mathrm{y})$, mean \pm SD & $41.35 \pm 10.52$ \\
\hline Gender & \\
\hline Male, $\boldsymbol{n}(\%)$ & $65(65 \%)$ \\
\hline Female, $\boldsymbol{n}(\%)$ & $35(35 \%)$ \\
\hline BMI, mean \pm SD & $25.17 \pm 4.14$ \\
\hline
\end{tabular}

Abbreviations: BMI, body mass index; SD, standard deviation.

Table 2 Surgical procedure details

\begin{tabular}{|c|l|}
\hline & Study group \\
\hline FAl etiology & \\
\hline Cam only, $\boldsymbol{n}(\%)$ & $30(86 \%)$ \\
\hline Pincer only, $\boldsymbol{n}(\%)$ & $1(3 \%)$ \\
\hline Combined Cam and Pincer, $\boldsymbol{n}(\%)$ & $4(11 \%)$ \\
\hline Labral treatment & \\
\hline Labral suture (\%) & $74(74 \%)$ \\
\hline Labrectomy (\%) & $26(26 \%)$ \\
\hline
\end{tabular}

Abbreviation: FAI, femoroacetabular impingement.

\section{Discussion}

The present study showed radiation exposure figures of $138.3 \mathrm{cGy} \mathrm{cm}^{2}$ to the operated patient, in line with the previously published. ${ }^{10}$ There is a relatively short time of exposure, mean 0.36 minutes in the present study, directly related to the surgical team's experience.

The aim of the team was to perform the minimum radiation exposure to the patients; mean 0.36 minutes, thus mean 21.6 seconds of radiation per surgical procedure. These outcomes agree with previous studies, with 0.32 minutes (19.2 seconds) in average of radiation exposure. ${ }^{10}$ In a recent study, Budd et al observed that the mean total fluoroscopy time was 1.10 minutes ( 66 seconds). ${ }^{11}$

Hip arthroscopy complications are mostly regarded to nerve lesions, technical problems during surgery or adhesions, and can reach ranges of $15 \%$ complications. The vast majority of complications are solved with no consequences. Most of these complications are related to the placement of portals. ${ }^{12}$ A few studies have described the radiation exposure during hip arthroscopy, ${ }^{10,11}$ and these focused on a possible relationship between the radiations received in the sex organs and a risk for the future fetus. ${ }^{9-11}$

Radiation exposure may cause skin lesions and even be incorporated to organs that could suffer changes in cellular deoxyribonucleic acid with a higher risk of dysplasia and carcinogenesis. ${ }^{11}$ There is an accepted and published calculation to rule out the skin entrance dose. ${ }^{13-15}$ Local radiation can cause skin lesions such as erythema, loss of skin or epithelial necrosis with doses from 200 to $1200 \mathrm{cGy} \mathrm{cm}{ }^{2}$, much higher than the values observed in the present study $\left(138 \mathrm{cGy} \mathrm{cm}^{2}\right)^{8,16}$
The recently described ultrasound-guided systems are of great interest to reduce these ranges of radiation. ${ }^{17,18}$ However, placing the arthroscopic portals with ultrasound is much more challenging than using fluoroscopy in a sterile environment. Given that radiation exposure during hip arthroscopy is 10 to 100 times less than the skin threshold tolerance, fluoroscopy offers a large safety margin. Total radiation during hip arthroscopy procedure is equivalent to 1.3 chest X-rays.

Several limitations have to be considered, although some are clearly inherent to it. The calculated doses are based in theoretical proportions that, very probably, have an interindividual variability based on their adipose tissue thickness, height of the fluoroscopic C-arm, or angulation. However, and besides these limitations, the theoretical calculation gives a very high safety margin.

\section{Conclusions}

Radiation exposure in patients undergoing a hip arthroscopy

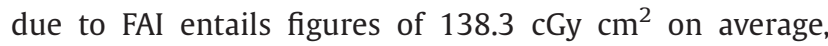
corresponding to 1.3 chest X-rays, very low from the safety limits recommended.

\section{Author Contributions Statement}

Roberto Seijas and David Barastegui were the surgeon of hip arthroscopy series and co-writers of the paper.

Miguel Angel Cepas and Jordi Catala were the radiologist who made the irradiation calculation.

Andrea Sallent and Oscar Ares performed the statistical analysis and language correction style of the paper.

\section{Conflict of Interest}

The authors declare that they have no conflict of interest.

\section{References}

1 Seijas R, Ares Ó, Sallent A. Indicaciones en artroscopia de cadera, exploración y evaluación de resultados Indications in hip arthroscopy, exploration and evaluation of outcomes. Rev Española Artrosc y Cirugía Articul 2016;23:11-18

2 Griffiths EJ, Khanduja V. Hip arthroscopy: evolution, current practice and future developments. Int Orthop 2012;36(06): $1115-1121$

3 Byrd JW. Hip arthroscopy utilizing the supine position. Arthroscopy 1994;10(03):275-280

4 Gobierno de España. Ministerio de la Presidencia. Real Decreto 1976/1999, de 23 de diciembre, por el que se establecen los criterios de calidad en radiodiagnóstico. Boletín Oficial del Estado

5 Consejo de la Unión Europea. Directiva 2013/59/EURATOM DEL CONSEJO de 5 de diciembre de 2013 por la que se establecen normas de seguridad básicas para la protección contra los peligros derivados de la exposición a radiaciones ionizantes, y se derogan las Directivas 89/618/Euratom, 90. Boletín Of Eur 2014;57 (L13):1-73

6 International Commission on Radiological Protection. ICRP Publication 105. Radiation protection in medicine. Ann ICRP 2007;37 (06):1-63

7 Mella C, Villalón I, Núñez Á. Complicaciones en artroscopia de cadera. Artroscopia fallida de cadera y artroscopia de revisión. Rev Española Artrosc y Cirugía Articul 2016;23:103-111 
8 Valentin J; International Commission on Radiological Protection. Avoidance of radiation injuries from medical interventional procedures. Ann ICRP 2000;30(02):7-67

9 Valentin J; International Commission on Radiological Protection. Low-dose extrapolation of radiation-related cancer risk. Ann ICRP 2005;35(04):1-140

10 Gaymer CE, Achten J, Auckett R, Cooper L, Griffin D. Fluoroscopic radiation exposure during hip arthroscopy. Arthroscopy 2013;29 (05):870-873

11 Budd H, Patchava A, Khanduja V. Establishing the radiation risk from fluoroscopic-assisted arthroscopic surgery of the hip. Int Orthop 2012;36(09):1803-1806

12 Seijas R, Ares O, Sallent A, et al. Hip arthroscopy complications regarding surgery and early postoperative care: retrospective study and review of literature. Musculoskelet Surg 2017;101(02):119-131

13 Chitnavis JP, Karthikesalingam A, Macdonald A, Brown C. Radiation risk from fluoroscopically-assisted anterior cruciate ligament reconstruction. Ann R Coll Surg Engl 2010;92(04):330-334
14 Heyd RL, Kopecky KK, Sherman S, Lehman GA, Stockberger SM. Radiation exposure to patients and personnel during interventional ERCP at a teaching institution. Gastrointest Endosc 1996;44 (03):287-292

15 Karthikesalingam A, Markar SR, Weerakkody R, Walsh SR, Carroll N, Praseedom RK. Radiation exposure during laparoscopic cholecystectomy with routine intraoperative cholangiography. Surg Endosc 2009;23(08):1845-1848

16 Koenig TR, Wolff D, Mettler FA, Wagner LK. Skin injuries from fluoroscopically guided procedures: part 1 , characteristics of radiation injury. AJR Am J Roentgenol 2001;177(01):3-11

17 Hua Y, Yang Y, Chen S, et al. Ultrasound-guided establishment of hip arthroscopy portals. Arthroscopy 2009;25(12):14911495

18 Howse EA, Botros DB, Mannava S, Stone AV, Stubbs AJ. Basic hip arthroscopy: anatomic establishment of arthroscopic portals without fluoroscopic guidance. Arthrosc Tech 2016;5(02):e247e250 